\title{
1. Did anyone notice the global financial crisis of 2007-2008?
}

On November 4, 2008, at the dedication of a new building, Queen Elizabeth of Great Britain visited the London School of Economics (LSE). While there she was given a briefing by academics at the LSE on the origins and effects of the global financial crisis and its resulting turmoil in international financial markets. The Queen is reported to have asked, "Why did nobody notice it developing?" The director of research at LSE told her, "At every stage someone was relying on somebody else and everyone thought they were doing the right thing."

How is it possible that the many intelligent investors, bankers, brokers, fund managers and other financial market participants thought they were doing the right thing, when it is clear in hindsight that market activity was creating a situation that ultimately caused global financial markets to collapse?

The answer lies in the fact that, for at least four decades, the economic theory that has dominated academic teaching has not been applicable to our economic system. This theory's teachings affected the economic reasoning of economic students who then became bankers, entrepreneurs, politicians, government regulators and so on. This theory is a fairy tale fable that has no descriptive relationship with the operations of our market oriented, money using, capitalist economy. Consequently, what was seen as a way of doing good in this fairy tale economy, created destructive economic forces in the world in which we live.

There were a few economists, however, that had a better understanding of how the modern market economy works. They did notice that financial markets were creating an unstable situation that, sooner or later, was going to cause a terrible financial markets problem. These economists called themselves Post Keynesians since they used and further developed the general theory that the 
English economist John Maynard Keynes had originated in 1936 to explain why the financial crisis precipitated by the New York Stock Market collapse in 1929 had created "the great depression" that encompassed the global economic system for years.

As early as 2002, in my Post Keynesian book Financial Markets, Money and the Real World, ${ }^{1}$ I noted that in modern market economies, the development of new well-organized markets for financial assets severed any direct link between the investment demand decision by entrepreneurs for the purchase of fixed capital plant and equipment and the savers' desire to earn as much as possible on their savings by making portfolio composition decisions (involving the ownership of financial assets including equities, debts, etc.).

The existence of well-organized financial markets, however, is a potential double-edged sword. The good edge of the sword is that such markets typically facilitate the transfer of funds which permits command over existing real resources from savers who do not want to use their funds today to buy things; to others, including investors, who want to obtain things in excess of what their own income earning claims would permit. In exchange, savers receive liquid financial assets such as stocks, bonds, mutual funds and so on in which they store their savings and hopefully earn more income while holding these assets in their portfolio of savings. These financial assets are deemed to be liquid in the sense that the savers believe that these financial assets can be readily sold for cash when, any time in the future, they wish to make a fast exit and return their savings to a cash reserve.

This good edge facilitates financing more capital goods investment including very large investment projects - projects often too large to be funded by any single individual or small group of partners. In so doing, the resulting investment projects typically increase productivity and reduce the costs of producing new goods and services for households to purchase.

The bad edge of the sword is that, in circumstances when many holders of these financial assets suddenly have increasing fears about what may happen in the uncertain future, the liquidity of these financial assets can evaporate as potential buyers disappear from the market. The result can be severe economic liquidity and insolvency problems that can engulf the global financial community. 
When regulators of the financial market permitted financial institutions to bundle together many illiquid mortgage debts to create mortgage backed derivatives (which encompassed subprime mortgages $^{2}$ in the mix) to then sell at a profit to savers, the seeds of financial catastrophe were being sowed. ${ }^{3}$ Savers were told that these securitized derivatives would provide holders with a larger return than could be obtained elsewhere (another apparent good) while these securities would maintain liquidity and be easily sold for cash.

This securitization process allowed many subprime mortgages to be bundled together with more conventional mortgages. This securitized bundling appeared to reduce the risk of an overall bad financial investment by savers since there would still be many in-good-standing mortgages in the bundle. Accordingly, these derivative securities were considered to be doing a social good in that more subprime mortgage loans could be made to allow many people to buy the homes they otherwise could not afford. Simultaneously, these derivative assets promised saver-holders of these derivative financial assets a larger rate of return than they could obtain by putting their savings elsewhere (e.g., into a money market account or even buying US government bonds) - another apparent good.

Since the initial packager of these securitized derivatives typically advertised that these financial assets were "as good as cash," that is, were readily liquidated for money in the market, the purchasers of these derivatives did not fear any significant loss if, and when, they decided to make a fast exit and sell their holdings of these derivatives. Moreover, rating agencies that profess to provide an objective report to the general public of the creditworthiness of such securitized financial assets gave these mortgage backed derivatives an AAA rating that further encouraged savers to believe that these derivatives were a safe investment for their funds.

No wonder, as the LSE director told the Queen, "everyone thought they were doing the right thing" for themselves and their economic community. But in 2007 these derivative and other new securitized markets appeared to collapse as many holders of these derivative securities became bearish and suddenly wanted to sell to make a fast exit from the market while no one apparently wanted to buy these derivatives offered for sale. The result was a liquidity 
crisis as these derivatives, now recognized as "toxic assets," lost all market value in the absence of sufficient buyers (bulls).

Accounting rules require that securities that are liquid and are held in one's balance sheet must be valued at the current market price on the asset side of the balance sheet. Since these toxic assets were held not only by individuals but also across the global financial community by bankers, pension funds and other institutional funds, the asset side of the balance sheets of these institutions collapsed, thereby damaging or destroying the accounting value of the net worth of the holders of these assets. The resulting financial crisis did not spare any important national economy.

In my book Financial Markets, Money and the Real World I noted that a financial crisis was likely to occur in the near future. I wrote that in the United States:

Recent trends in the growth of mutual funds and other nonbank financial intermediaries have encouraged saver households to reallocate their saving portfolio from holding (government insured) bank deposits towards holding more liabilities [issued by] nonbank financial intermediaries. This has permitted a significant expansion of debt obligations on the part of debtor households and enterprises. This suggests that a sudden switch by many [portfolio holding savers] ... to a fast exit strategy at a future date could cause a horrific liquidity problem. ${ }^{4}$

The global financial crisis of 2007-2008 indicates how prophetic this 2002 Post Keynesian message proved to be.

As we will discuss in later chapters, the Post Keynesian analytical system can suggest ways to dull the bad edge of liquid financial markets swords via (1) legislating proper regulatory rules on financial markets and (2) having central banks ready to alleviate a financial liquidity crisis if it still occurs. Accordingly, a major purpose of this book is to explain, not only to Queen Elizabeth but to all, why what is the mainstream's fairy tale classical economic theory is still being espoused by the talking head "experts" and "elites" on TV and in governments, central banks and even international institutions such as the International Monetary Fund (IMF), while, though still often ignored, the Post Keynesian approach is available to provide a realistic analysis of the operation of the money using capitalist economy in which we live. Once we understand the operation of a 21st-century market oriented, money using world economy as explained by Post Keynesian analysis, we 
shall then understand why the policies necessary to deal with economic problems when they occur will be significantly different than those often espoused by such elite experts.

\section{NOTES}

1. P. Davidson, Financial Markets, Money and the Real World (Edward Elgar, Cheltenham, UK and Northampton, MA, 2002) Chapter 6.

2. A subprime mortgage is a loan made to individuals to help purchase a home. These individuals typically are poor credit risks, often are unable to prove income earnings and possess few, if any, other assets that can be pledged as collateral. The sub prime loan typically involves high origination fees, prepayment penalties, balloon maturities and other costs that make it difficult to refinance the loan if interest rates decline. Often the loan comes with an artificially low introductory rate that ratchets upward substantially thereby increasing monthly payments by as much as 50 percent.

The good was that these subprime loans increased opportunities for home ownership, adding nine million US households to the number of homeowners in the decade from 1996 to 2006. Often this permitted the poor to gain the American Dream of home ownership.

The bad is that when monthly payments rose on these types of loans the default rate became very large.

3. At this point we illustrate the problem with the securitization of mortgage backed derivative securities. But at the same time, other exotic securities such as credit default swaps were being invested and sold to the public which had similar faults.

4. Op. cit., p. 117. 